\title{
Peripartal Excretion of Eimeria Oocyst by Cows on Swedish Dairy Farms and the Age of Calves at First Excretion
}

\author{
By C. Svensson
}

Experimental Station, Veterinary Institute, Swedish University of Agricultural Sciences, Skara, Sweden.

\begin{abstract}
Svensson, C.: Peripartal excretion of Eimeria oocysts by cows on Swedish dairy farms and the age of calves at first excretion. Acta vet. scand. 1993, 34, 77-81. - Faecal samples were collected 3 times a week for 6 weeks from 22 peripartal cows and for up to 15 weeks after birth from 27 calves in 3 herds, to determine the numbers of Eimeria oocysts excreted and the age at which the calves first excreted oocysts. Only low numbers of oocysts were excreted by the cows and no oocysts were detected in $93 \%$ of the samples. However, half the cows excreted oocysts at least once. The age at which the calves first excreted oocysts ranged from 2.5 to at least 15 weeks, and there was a significant difference between the herds in their mean age at first excretion. Oocysts of Eimeria alabamensis, E. auburnensis, E. bovis and E. ellipsoidalis were found in numbers ranging from 7 to 8450 oocysts per gram faeces. About $50 \%$ of the calves excreted oocysts before they were transferred to group pens. The primary source of infection of the calves was probably their penmates or the previous occupants of the pens, and the cows probably played a subsidiary role.
\end{abstract}

coccidiosis; protozoal infection; diarrhoea

\section{Introduction}

Eimeria is a genus of coccidian parasites which belongs to the protozoan phylum Apicomplexa. At least 13 species of Eimeria are known to infect cattle. Eimeria bovis and E. zuernii are considered to be the most pathogenic, but $E$. alabamensis, E. auburnensis, E. ellipsoidalis and E. wyomingensis can cause marked clinical signs if they are present in large numbers. The pathogenic significance of the other species is uncertain (Bürger 1983).

Coccidiosis is primarily a disease of young animals and in cattle it occurs most commonly in calves aged 3 weeks to 6 months (Levine 1985). Adult cattle are generally resistant to clinical coccidiosis but they can carry subclinical infections which may be a source of infection for calves (Ernst \& Benz 1981).

In Sweden dairy calves have traditionally been removed from their dams immediately after birth, a procedure which helps to prevent the transmission of diseases from the cow to its calf. However, in recent years it has become more common to use calving boxes, and this practice may increase the risk of transmitting infections.

The aims of this study were to quantify the excretion of oocysts by peripartal dairy cows, to determine the age at which calves first excrete oocysts, and to use these data to try to identify the primary source of infection for early appearing coccidiosis in dairy calves under Swedish conditions.

\section{Materials and methods}

The study was made between August 1990 and May 1991 and used 3 dairy farms (A, B and C) in south-west Sweden, each with between 40 and 
65 cows. Originally 25 cows and 30 calves were selected; 10 cows and their calves from each of the herds $B$ and $C$ and 5 cows and their calves from herd $\mathrm{A}$ together with 5 additional calves from this herd. The cows and their calves were of the Swedish Red and White breed except for 3 Friesian cows and their calves in herd B. Four of the cows were first calvers but all the others were multiparous. In herd A frequent problems with clinical coccidiosis had previously been recorded in heifer calves aged 2.5 to 4 months. Clinical coccidiosis had not been suspected in the other 2 herds.

\section{Management and feeding}

Herd A. - The cows were tied in long stalls; 2 to 3 days before calving they were moved to boxes where they stayed with their calves until 2 days after calving. The calves were then moved to individual pens in a separate section of the same shed where they were bedded on straw. They were fed whole milk for the first 4 days and then milk replacer. Hay was supplied from the first day and concentrates after they had been in the calf pens for a week. The calves were weaned at 7 to 8 weeks of age and 2 to 3 weeks later the bull calves were moved to a separate fattening section and tied up; the heifer calves were transferred to another shed accommodating young stock where they were housed in groups of 8 in pens with slatted floors.

Herd B. - The cows were kept in a loose house system but tied in long stalls during the periparturient period. The calves were removed from their dams immediately after birth and put in individual pens bedded with straw. The feeding and weaning routines were similar to those in herd A. When they were 5 to 7 weeks old, the calves were transferred to group pens which had a dunging passage with a slatted floor and a lying area bedded with wood shavings, where they were housed in groups of 6 to 8 calves.
Herd C. - The cows were tied in long stalls. They calved in boxes but the calves were removed within a few $h$ of birth and housed in pens, either individually or in pairs. At approximately 2 months of age they were weaned and transferred to group pens with slatted floors, housing 5 to 6 calves. The feeding routines were very similar to those in herds A and B.

\section{Collection of samples, counting of oocysts and species differentiation}

Faecal samples were taken directly from the rectum of the cows 3 times a week from 2 weeks before until 4 weeks after calving. Faecal samples were obtained from the calves either from the rectum or fresh from the pen floor 3 times a week from birth until the first excretion of oocysts or, if no oocysts were found, until they were 15 weeks of age. The samplings were carried out by the author (herds B and C) and the herdsmen (herd A).

The number of oocysts per gram of faeces (opg) was counted using a modified McMaster method (D. Blewett, pers. comm.): $1 \mathrm{~g}$ of faeces was mixed with $10 \mathrm{ml}$ of water and passed through a 150 mesh sieve. The filtrate was centrifuged at $1000 \mathrm{x}$ g for $5 \mathrm{~min}$. The pellet was resuspended in $10 \mathrm{ml}$ saturated sodium chloride solution and centrifuged at $1000 \mathrm{~g}$ for $5 \mathrm{~min}$. The top $1 \mathrm{ml}$ of the supernatant was withdrawn, mixed and placed in a McMaster counting chamber. The number of oocysts per chamber was divided by 0.15 to give the number of opg. The oocysts were differentiated into species on the basis of the morphology of the unsporulated oocysts (Joyner et al. 1966).

\section{Statistics}

The differences between the ages of the calves when they first excreted oocysts were analysed by means of the Kruskal-Wallis test. Comparisons between pairs of data were made by using Mann-Whitney U statistics (Altman 1991). 
Table 1. The number of cows and calves studied in the 3 dairy herds.

\begin{tabular}{cccc}
\hline Herd & Cows & \multicolumn{2}{c}{ Calves } \\
\cline { 3 - 4 } & & Female & Male \\
\hline A & 4 & 5 & 5 \\
B & 9 & 6 & 3 \\
C & 9 & 6 & 2 \\
\hline
\end{tabular}

Table 2. The median ages, and ranges of ages, at which Eimeria oocysts were first excreted by 27 calves in the 3 dairy herds.

\begin{tabular}{lcll}
\hline \multirow{2}{*}{ Herd } & \multicolumn{1}{c}{ Age (weeks) } & \multicolumn{1}{c}{ Species } \\
\cline { 2 - 3 } & Median Range & \\
\hline A & 13.5 & $7.0->15$ & $\begin{array}{l}\text { E. alabamensis, E. auburnen- } \\
\text { sis, E. bovis, E. ellipsoidalis }\end{array}$ \\
B & 6.5 & $3.5-9.5$ & $\begin{array}{l}\text { E. alabamensis, E. bovis, } \\
\text { E. alabamensis }\end{array}$ \\
C & 3.5 & $2.5-6.0$ & alabamen \\
\hline
\end{tabular}

* Species not determined in 2 calves.

\section{Results}

In $399(93 \%)$ of the 429 samples of faeces obtained from the cows, no oocysts were detected. However, between 1 or 6 positive samples (mean 2.7 samples) were obtained from 11 (50\%) of the cows. Apart from 1 specimen obtained from herd A, which contained 167 opg, they all contained less than 50 opg. The oocysts belonged to the species E. alabamensis, E. bovis, E. subspherica and E. zuernii.

Oocysts were first excreted by the calves when they were between 2.5 and at least 15 weeks old (Table 2). Two (7\%) of the calves, both of them from herd A, excreted no oocysts during the observation period. When they first excreted oocysts the calves in herd A were significantly older than the calves in the other 2 herds $(\mathrm{p}=$ 0.0030 ) and the calves in herd $B$ were significantly older than those in herd $\mathrm{C}(\mathrm{p}=0.0027)$. Four $(40 \%)$ calves in herd A and $1(11 \%)$ calf in herd $\mathrm{B}$ shed oocysts while they were housed in indi- vidual pens. In herd $\mathrm{C}$ all 8 calves excreted oocysts before transfer to group pens. From the calves which excreted oocysts within the observation period, 1 to 12 (mean 3.6) positive samples were collected. The numbers of opg ranged from 7 to 8450, and they exceeded 1000 in 11 samples from 6 calves, of which 4 came from herd $\mathrm{B}$ and 2 from herd C. Four species of Eimeria were identified and 2 of these, E. auburnensis and E. ellipsoidalis, were not identified in the samples from the cows (Table 2). None of the calves showed clinical signs of coccidiosis.

\section{Discussion}

Bejsovec (1986) examined faecal samples presumably taken on only one occasion from 43 cows in new calving pens and found that $38(88 \%)$ of them were excreting oocysts of Eimeria species. Furthermore, because the calves excreted oocysts already during their first few days of life, it was concluded that the cows were an important source of infection for their calves. The numbers of oocysts were similar or slightly larger than in the present study, in which only half the cows excreted oocysts during the period of observation. If, in the present study, the cows had been examined on only one occasion - probably a fairer comparison with the results of Bejsovec - even fewer cows would have been detected excreting oocysts. Thus, even though in the present study only 10 calves were kept with their dams, the results conflict with those of Bejsovec and suggest that under Swedish conditions cows constitute a possible but probably insignificant source of infection for their calves.

The range of ages at which the calves began to excrete oocysts was in agreement with the results of Davis \& Bowman (1952) and Pavlásek (1975). Hiepe et al. (1978) found that $13 \%$ of calves kept in individual pens excreted oocysts; the average proportion observed in this study was higher. In herd A 4 of the calves (40\%) excreted oocysts while they were housed in individu- 
al pens. However, considering the prepatent periods of the 4 species found, 6-24 days (Levine 1975), it is likely that the rest of the calves in this herd became infected while they were in the fattening section or the accommodation for young stock. In herd B 4 of the calves which first excreted oocysts while in the group pens may have become infected already while they were housed in individual pens.

In the present study large differences were found in the median age at which the calves in the 3 herds started to excrete oocysts. The age at which a calf begins to excrete oocysts would be expected to be related to the degree of contamination of the calf's environment with oocysts. The differences observed were probably due to differences in the level of contamination of the individual and group pens used to accommodate the calves. The factors which might have influenced the level of contamination include the standard of hygiene on the farms and the immunological status of the calves. However, Eimeria species have a high reproductive potential and are resistant to environmental influences so that very small increases in the intake or excretion of oocysts may have dramatic effects on the contamination of the animal accommodation.

Clinical coccidiosis occurs very commonly a few weeks after calves have been transferred to pens where they are confined closely together (Herrick 1990). Pavlásek et al. (1984) demonstrated the value of individual pens for preventing coccidial infection and concluded that contaminated group pens are a major source of infection. The results of the present study indicate that calves often become infected while they are in individual pens. It seems highly reasonable that such calves subsequently are the source of heavy contamination of the group pens and thereby could induce coccidiosis in calves later moved to the pens, as was previously proposed by Bejsovec (1986).

\section{Acknowledgements}

The author is indebted to the staff of the farms for taking faeces samples and for their interest, to Ms. Helena Olofsson for laboratory work and Drs. Bo Pehrson, Mats Törnquist and Arvid Uggla for help in planning and preparing the study. The investigation was supported financially by the Swedish Farmers' Foundation for Research.

\section{References}

Altman DG: Practical Statistics for Medical Research. Chapman and Hall, London, 1991, p. 213-215

Bejsovec J: The infection of calves by endoparasites in calving pens and calving houses. Acta vet. Brno 1986, 55, 197-206

Bürger HJ: Eimeria-Infektionen beim Rind (Eimeria infections in cattle). Berl. Münch. Tierärztl. Wschr. $1983,96,350-357$

Davis LR, Bowman GW: Coccidiosis in Cattle. Proc. U. S. Livestock San. A. 1952, 39-50

Ernst JV, Benz GW: Coccidiosis. Curr. Top. Vet. Med. Anim. Sci. 1981, 6, 377-392

Herrick JB: Conquering coccidia. Subclinical cases demand veterinary know-how. Large Anim. Vet. 1990, 45 (5), 29-30

Hiepe T, Romeyke D, Jungmann J: Untersuchungen über Kokzidien-Infektionen des Kalbes unter den Bedingungen der industriemäßigen Rinderproduktion mit einem Beitrag zur Bekämpfung. (Studies of coccidia infections in calves in industrial production with special reference to control). Mhft. Vet. med. 1978, 33, 904-910

Joyner LP, Norton CC, Davies SFM, Watkins CV: The species of coccidia occurring in cattle and sheep in the South-West of England. Parasitology 1966, 56, 531-541

Levine ND: Veterinary Protozoology. Iowa State University Press, Ames, 1985

Pavlásek I: Age fluctuation of calf coccidiosis in a large-scale calf house. J. Protozool. 1975, 22, 68 A

Pavlásek I, Celeda L, Urbanova Z, CernyJ, Raskova $H$ : Coccidiosis in preruminating calves. The effect of management and short-term treatment on the spread of infection and reinfection. Vet. Parasit. 1984, 14, 7-12

\section{Sammanfattning}

Utskiljning av Eimeria oocystor hos svenska mjölkkor under peripaartal perioden och åldern hos kalvaar vid första oocystutskiljningen. 
Träckprover togs 3 gånger per vecka under 6 veckor på 22 peripartala kor och under upp till 15 veckor efter födelsen på 27 kalvar från 3 besättningar för bestämning dels av antalet Eimeria-oocystor dels av åldern hos kalvarna vid den första oocystutskiljningen. Korna utskiljde oocystor endast i lågt antal och inga oocystor kunde återfinnas i $93 \%$ av proverna. Dock påvisades oocystor i träcken hos hälften av korna vid minst ett tillfälle. Kalvarna utskiljde oocystor för första gången vid 2,5 till 15 veckors ålder, och en sig- nifikant skillnad förelåg mellan besättningarna vad gäller medelåldern vid den första utskiljningen. Oocystor av Eimeria alabamensis, E. auburnensis, E. bovis och E. ellipsoidalis påvisades i ett antal av 7-8450 per gram faeces. Hos cirka $50 \%$ av kalvarna kunde oocystutskiljning ses i enkalvs- eller parboxar. Den primära infektionskällan för kalvarna utgjordes troligen av boxkamrater eller kalvar som tidigare inhysts i boxarna, medan korna sannolikt spelade en underordnad roll.

(Received November 11, 1992; accepted November 18, 1992).

Reprints may be requested from: C. Svensson, Experimental Station, Veterinary Institute, Swedish University of Agricultural Sciences, P.O. Box 234, S-532 23 Skara, Sweden. 
